\title{
Hydrodynamic conditions of the banda and northern arafura seas in the northwest monsoon (februay2014)
}

\author{
Abdul Basit ${ }^{1 *}$, Pipit Pitriana ${ }^{1}$, Hanung Agus Mulyadi ${ }^{1}$, Abd. Wahab Radjab ${ }^{1}$, Mutiara Rachmat Putri ${ }^{2}$, \\ Bernhard Mayer ${ }^{3}$, Thomas Pohlmann ${ }^{3}$ \\ ${ }^{1}$ Deep Sea Center-LIPI, Jl. Y. Syaranamual, Guru-guru Poka, Ambon, Maluku, Indonesia 97233 \\ ${ }^{2}$ Research Groups on Oceanography - Bandung Institute of Technology,Jl. Ganesha No.10 Bandung, Indonesia 40132 \\ ${ }^{3}$ Institute of Oceanography, University of Hamburg, Hamburg, Germany 20146
}

ARTICLE INFO ABSTRACT

\section{Article history:}

Submitted 11 September 2021

Revised 22 November 2021

Accepted 30 November 2021

Published online 3 December 2021

\section{Keywords:}

Banda and northern Arafura Seas, downwelling, HAMSOM,

northwest monsoon,

upwelling

\begin{abstract}
The physical and hydrodynamic conditions in the Banda and Northern Arafura Seas (BAS) during northwest monsoon (February 2014) were investigated using a three-dimensional baroclinic nonlinear numerical model-the Hamburg Shelf Ocean Model (HAMSOM). This study found that northwesterly winds induced eastward surface currents that transported relatively fresh water from the Flores Sea to the Arafura Sea via the Banda Sea. It was also found that the westerly surface currents carried relatively cold water induced by upwelling along the northern coast of the Lesser Sunda Islands. Furthermore, the simulation results revealed that relatively saline surface water from the Indian Ocean intruding through the Ombai Strait and Timor Passage contributed to the surface water of the Eastern Banda Sea and Aru Basin being more saline than the surrounding water. Part of the surface water sank as a result of downwelling in the Arafura Sea. The BAS had higher salinity than the Makassar Strait at a depth of $75-300 \mathrm{~m}$. The simulation results suggested that the higher salinity was due to the influence of the South Pacific Subtropical Water (SPSW) that entered the Indonesian Seas primarily through the Halmahera Sea.
\end{abstract}

(C)2021 Indonesian Institute of Sciences (LIPI)

\section{Introduction}

The Banda and Northern Arafura Seas (BAS) are located next to each other (Figure 1). They are separated in the middle by the Kai Islands. During the northwest monsoon (December-February), northwesterly winds were dominant in exposing the surface waters of the seas (Wyrtki, 1961) roads, and pavement. Downwelling was induced around the BAS due to the semi-enclosed nature of the Northern Arafura Sea (Wyrtki, 1961) roads, and pavement. Such downwelling plays an important role in the survival of benthic animals, allowing the oxygenation of deep ocean water ( $>200 \mathrm{~m}$ depth) by bringing dissolved oxygen down from the surface. Without this process, the available oxygen within the water column would quickly be exhausted through biological processes; very few benthic animals could survive such a situation, and mass extinction would occur (Explorer, 2021). In contrast, northwesterly winds led to upwelling along the northern coast of the Lesser Sunda Islands, inducing colder sea surface temperatures (SST) and a positive anomaly of chlorophyll-a in the western Banda Sea (Wirasatriya et al., 2021)

Within the internal salinity maximum layer $(50-300$ $m$ depth), the Indonesian Seas were exposed to North Pacific Subtropical Water (NPSW; around 90\%) and South Pacific Subtropical Water (SPSW; around 10\%) (Gordon et al., 2010; Mayer et al., 2010; Sprintall et al., 2014). The NPSW was mostly transported through the Makassar Strait (termed the western Indonesian Throughflow) before entering into the BAS and then exiting into the Indian Ocean through the Ombai Strait and Timor Passage. The remaining water masses (the SPSW) were transported mostly through the Halmahera and Seram Seas (collectively termed the eastern Indonesian Throughflow) before entering into the BAS. The SPSW can be distinguished from the NPSW by its higher salinity maximum; the NPSW in the Indonesian Seas is generally characterized by a salinity maximum of between 34.4 and 34.8 , while the SPSW is generally characterized by a salinity maximum of $>34.8$ (Wyrtki, 1961; Gordon, 2005; Koch-Larrouy et al., 2007). Moreover, the SPSW is relatively warmer than the NPSW. Such a characteristic was noted in Weda Bay, which is directly connected to the Halmahera Sea; a salinity maximum of about 35 was found at $160 \mathrm{~m}$ depth at the end of the northwest monsoon (March 13-23, 2013) (Basit and Putri, 2013). By applying a numerical simulation, it was found that the SPSW was transformed by tidal mixing in the Halmahera Sea, reducing the salinity of this area's water to below that of the SPSW (Gordon, 2005; Koch-Larrouy et al., 2007).

This research aims to investigate the physical and hydrodynamic conditions during the northwest monsoon (February 2014). For this purpose, this paper is organized as follows: following this introduction (Section 1), it describes the model setup and validation (Sections 2 and 3, respectively). The results and discussion of the simulation are presented in Section 4. Finally, the conclusions of this study are presented in Section 5. 


\section{Model setup}

This study applied the Hamburg Shelf Ocean Model (HAMSOM) designed and developed by Backhaus (1985), Pohlmann (1997a,1997b,2006), and their colleagues. The bathymetry of a 30-second resolution grid of the Shuttle Radar Topography Mission (SRTM) was linearly interpolated to obtain a 3-minute resolution bathymetry for the region. The model domain expands from $114^{\circ} \mathrm{E}$ to $139^{\circ} \mathrm{E}$ and from $14^{\circ} \mathrm{S}$ to $12^{\circ}$ $\mathrm{N}$ (Figure 1).

The initial and open boundary conditions were obtained from the Max Planck Institute's Global Ocean/Sea Ice Model (MPI-OM) (Marsland et al., 2002; Jungclaus et al., 2006) and the simulation of key oceanic features, such as sea surface temperatures (SSTs). Vertical layer thickness increased gradually towards the sea bottom, to better represent the mixed and internal salinity maximum layers.
A bulk formula was applied to calculate the fluxes of momentum, heat, and freshwater at the sea surface. Atmospheric forcing were obtained from the National Center for Environmental Prediction (NCEP) (Kalnay et al., 1996). They included atmospheric sea surface pressure, air temperature, specific humidity, u-wind, $\mathrm{v}$-wind, and precipitation rate. The simulation was also forced by daily river discharge data regarding which was obtained from the Water GAP Global Hydrology Model (WHHM) with a spatial resolution of $0.5^{\circ}$ (Kaspar et al., 2003). Eleven tidal components (M2, S2, K1, O1, Q1, P1, N2, K2, M4, MS4, Mn4) derived from a TOPEX/POSEIDON global tidal model (TPXO.6.2) (Egbert et al., 1994; Egbert and Erofeeva, 2002) were explicitly forced in the simulation. The approach of (Kochergin, 1987) was used to calculate the vertical turbulent viscosity coefficient; a more detailed description can be seen in Basit (2019).

To support the full-model simulation, i.e. including wind, river, and tide (WRT), three additional experiments (Table 1)

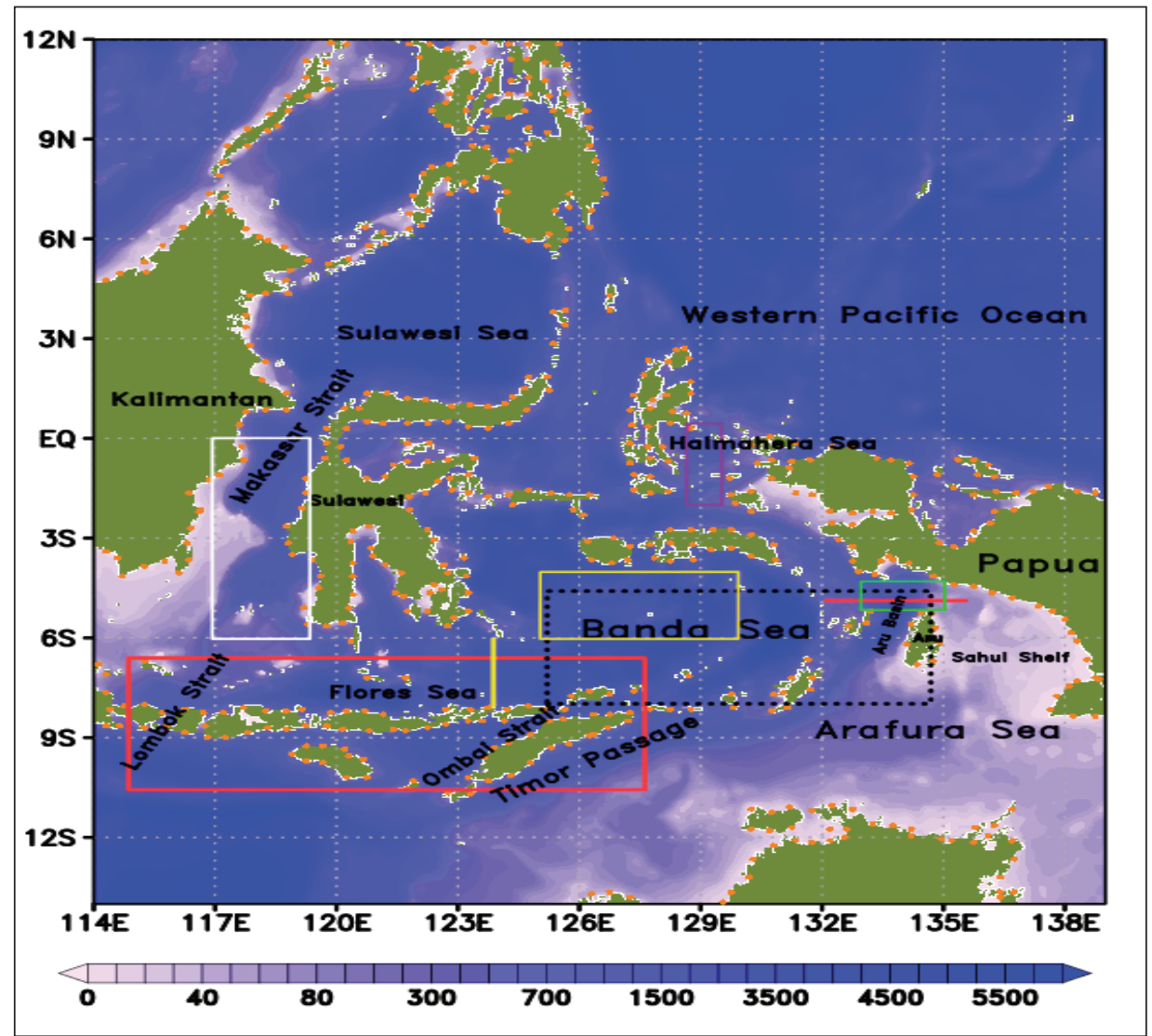

Figure 1. Topography of the model area, in meters. The red rectangle is the Lesser Sunda Islands. The solid orange circles along the coastline represent the river locations. The yellow and red lines (Sections A and B) delineate the regions representing upwelling and downwelling centers during the northwest monsoon. The purple (Halmahera Sea), green (Northern Arafura Sea), yellow (Banda Sea), and white (Makassar Strait) rectangles indicate the regions where the T-S diagrams were plotted. The dotted line indicates the regions where the daily SST was plotted for validation.

Table 1. Numerical experiment design

\begin{tabular}{lllll}
\hline No & Experiments & Wind & River runoff & Tidal elevation \\
\hline 1 & Control run (WRT) & Y & Y & Y \\
\hline 2 & No-River (WT) & Y & N & Y \\
\hline 3 & No-Tide (WR) & Y & Y & N \\
\hline 4 & Wind only (WO) & Y & N & N \\
\hline
\end{tabular}


were performed to investigate the influence of river run off and tidal forcing on upwelling during the northwest monsoon. These three additional experiments were conducted by excluding river discharge (WT), excluding tidal forcing (WR), and excluding both (WO). Results were compared with the control run(WRT). Spin-up was performed by running all experiments for the two years (from 2012 to 2013) before the investigation period.

\section{Model validation}

The monthly average SST for February 2014 showed good agreement (Figure 2), as indicated by comparing the simulation results with the Moderate Resolution Imaging Spectro radio meter Satellite (MODIS) (Kilpatrick et al., 2015). Employing a qualitative visual comparison, some cold areas were found around the northern coast of the Lesser Sunda Islands and the South western Banda Sea during the northwest monsoon, both in the simulation and in the satellite data. By ascertaining the daily average BAS (Figure 3) throughout 2014, it was found that seasonal variations were evident in the HAMSOM and MODIS data. A warmer SST was found during the northwest monsoon (December-February 2014), while a colder SST was found during the southeast monsoon (May-September 2014). The Pearson correlation ( $\mathrm{r}$-cor) between the data shows strong correlation $(\mathrm{r}=0.89)$.

The results of the four simulation experiments-the WRT (redline), WO (yellow line), WR (blue line), and WT (green line) cases-were compared with the observed EN4 data (cyan line), which were based on data taken from all instruments able to profile the water column (https://icdc.cen.uni-hamburg.de/ en/en4.html) in the selected areas, i.e. the Halmahera Sea, Banda Sea, Makassar Strait and the northern Arafura Sea (Figure 1) for the year 2014 (Figure 4). In general, the simulated T-S diagram found a generally good agreement between the WRT case and the observed data (the EN4 data). In the selected areas, the salinity maximum deviated by $0.1-0.2$ between the observation and the WRT cases. In all selected areas, the deviations were larger

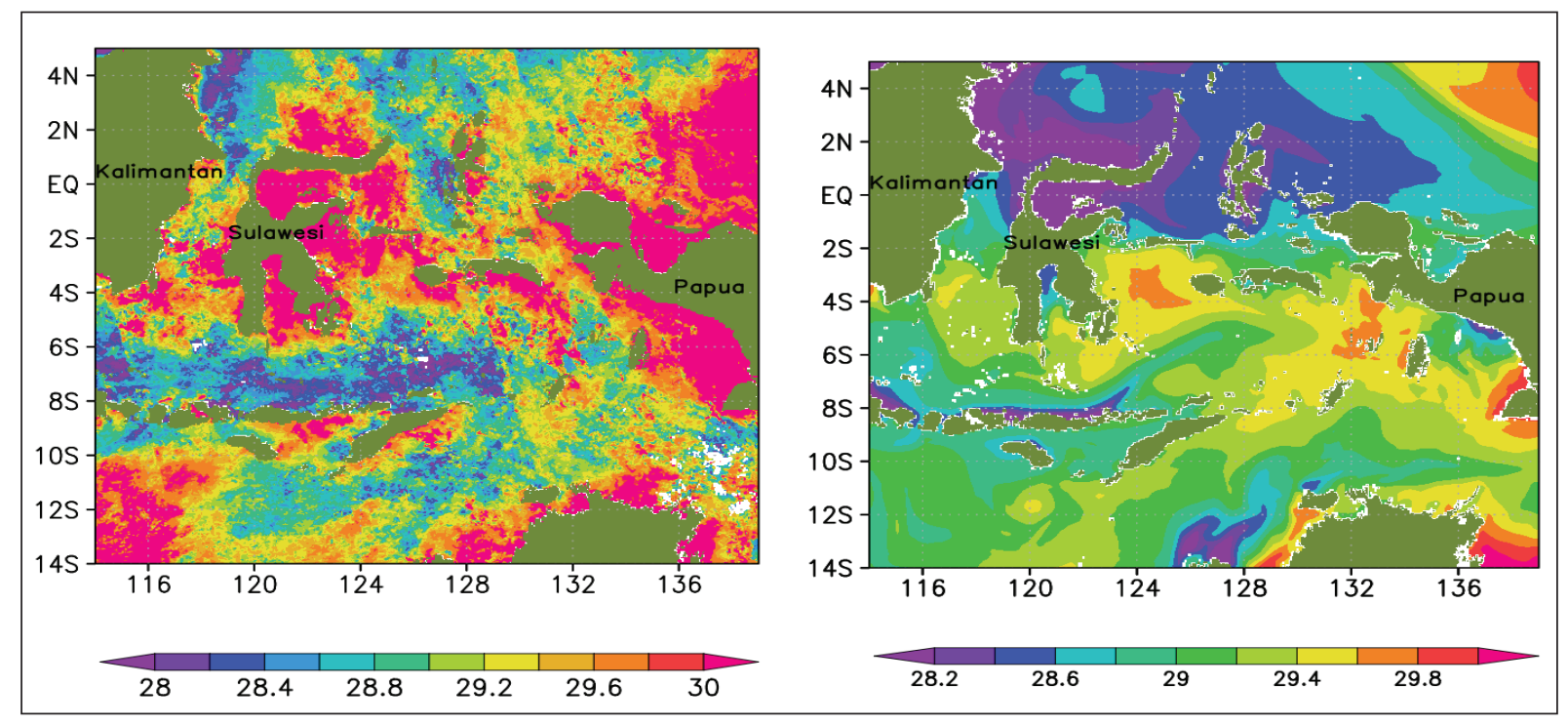

Figure 2. Monthly averaged SST ( ${ }^{\circ} \mathrm{C}$ ) comparison between the MODIS (left) and HAMSOM (right) in the period of February 2014.

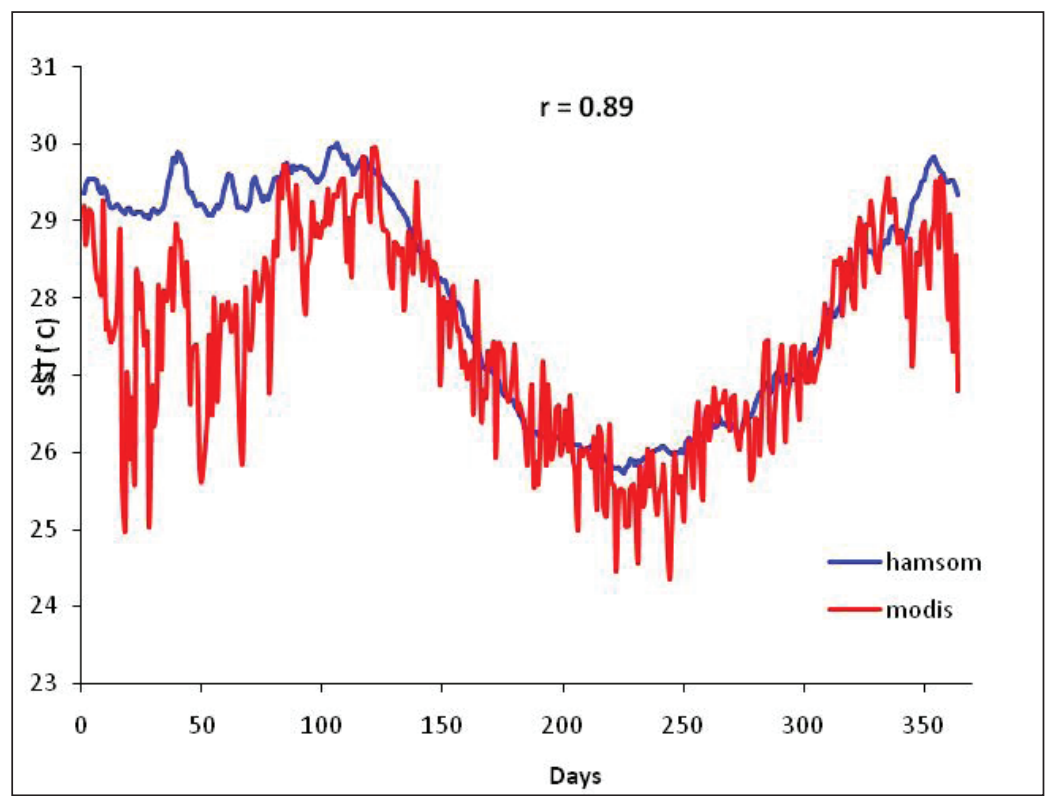

Figure 3. Daily sea surface temperature of HAMSOM and MODIS in 2014 over the Banda and Arafura Seas $\left(8-4^{\mathrm{S}} \mathrm{S} / 125-135^{\circ} \mathrm{E}\right)$, see also Figure 1. 

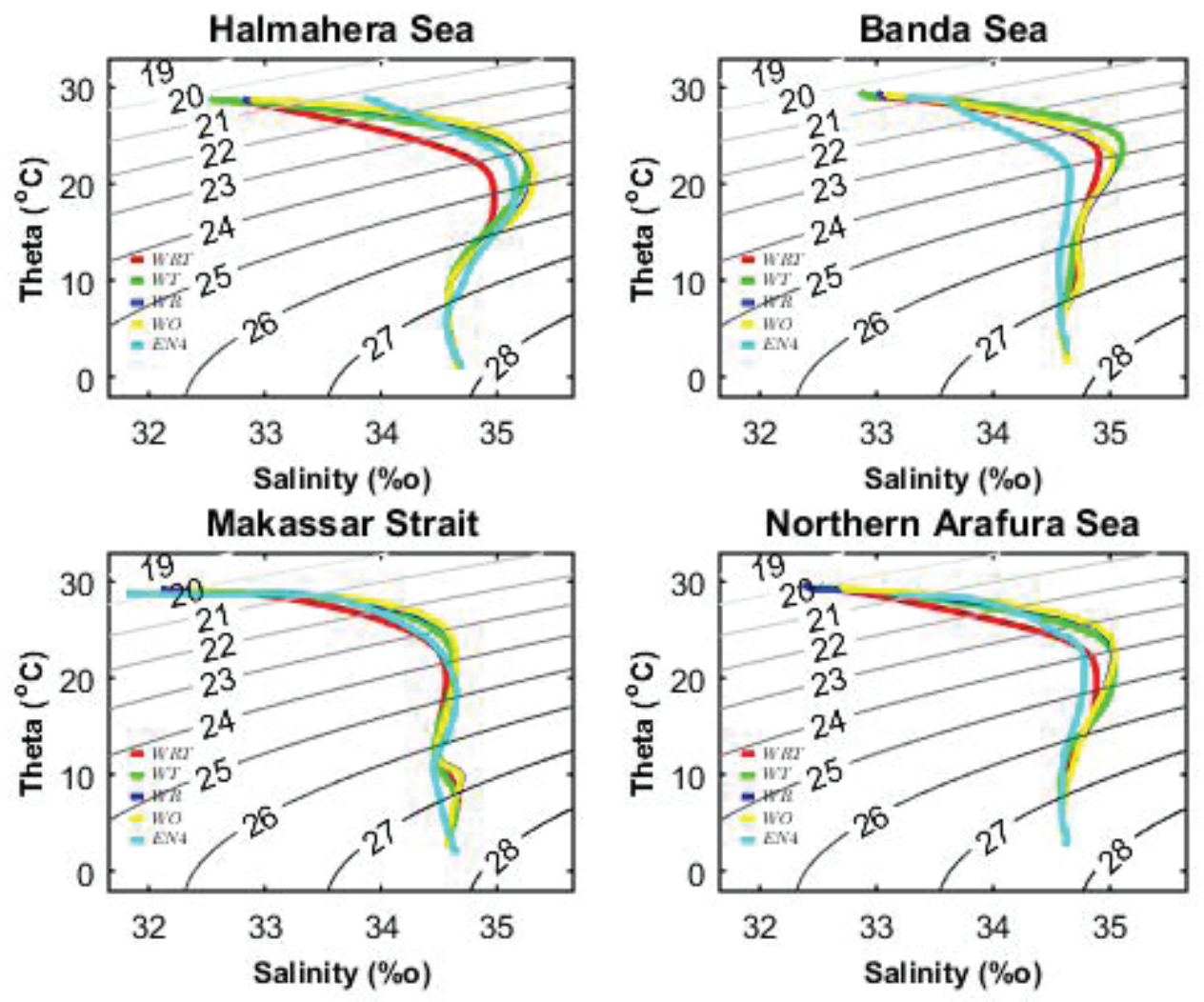

Figure 4. T-S diagram derived from HAMSOM simulations and observation data (EN4), monthly averaged for the February 2014 period in the selected areas i.e. Halmahera, Banda Sea, Makasssar Strait and Northern Arafura Seas (Right): the WRT case (red), the WO case (yellow), the WR case (blue), the WT case (green), and measured data (cyan).

and tended to be overestimated when tidal forcing was excluded (i.e., in the WR case). The simulation results also show that river forcing plays an important role in producing a better estimate when the tide is also included. When the river forcing was excluded from the simulation (i.e., in the $\mathrm{W}^{\prime} \mathrm{T}$ case), the salinity maximum in all selected areas becomes higher, resulting in a larger deviation. This condition indicates that strong tidal mixing uplifts deep water to the surface, where it mixes with fresher water, thereby reducing the salinity of the thermocline layer. This is also indicated by the higher vertical turbulent diffusivity of the tidal simulation (figure not shown). The results show that the strongest tidal mixing occurs in the Halmahera Sea, this confirms the findings of (Koch-Larrouy et al., 2007), as indicated by the salinity maximum being most different between the WRT and WR cases. In contrast, river forcing contributed relatively little to the eroded salinity maximum when tidal forcing was excluded, as indicated by comparing the WR and WO cases.

A more detailed validation of other parameters, including sea surface height (SSH), velocity, long-term SST (1990-2014), and TS-Diagram, can be found in (Basit, 2019)

\section{Results and discussion}

In general, circulation patterns were similar in the four experiments. However, the simulation results from the WRT case are discussed in more detail here because they quantitatively provide a better approximation, as discussed above (TS-diagram). During February 2014, northwesterly winds mostly blew over the Indonesian Seas (Figure 5). The winds induced eastward currents that brought relatively freshwaters from the Makassar Strait and the Java Sea through the Flores Sea, from which it crossed the Banda Sea before entering the Northern Arafura Sea (Figure 6). The currents also brought relatively cold water that reduced the SST of the southwestern and central Banda Sea. Within the internal salinity maximum layer (75-300 $\mathrm{m}$ depth), the simulation results showed that the water masses of the Banda Seas were influenced partly by the Northwestern Pacific Ocean, which entered the Sulawesi Sea before crossing in tothe Makassar Strait and then the Flores Sea (Figure 7). The more detailed hydrodynamic conditions of the BAS are discussed below.

\subsection{Upwelling and its impact on the surface water of the Banda Sea}

The simulation results show that colder SSTs were found in the western and center Banda Sea. This suggests that the colder SSTs were induced by coastal upwelling which occurred around the northern coast of the Lesser Sunda Islands, resulting in SST being relatively colder near the coast than in surrounding waters. The northeastward currents brought the cold waters into the Banda Sea, inducing a colder SST in the southwestern and central Banda Sea (28.8-29.2을 as opposed to 29.4-29.8ㅇ) (Figure 6). Sea surface salinity (SSS) was expected to be higher than in surrounding water as a consequence of upwelling, but this was not found (Figure 6). A relatively higher SSS, indicative of upwelling, was only found along the northern coast of the Lesser Sunda Islands. It was also noted that the SSS of the northern Banda Sea was less than that of the southern Banda Sea. This study suggests two reasons for the water in the Flores and Banda Seas being relatively fresher. First, the water of the northern Flores Sea mostly originated from the Java Sea and Makassar Strait, and this induced low salinity in the northern Banda Sea. Secondly, the surface waters of the BAS were also 


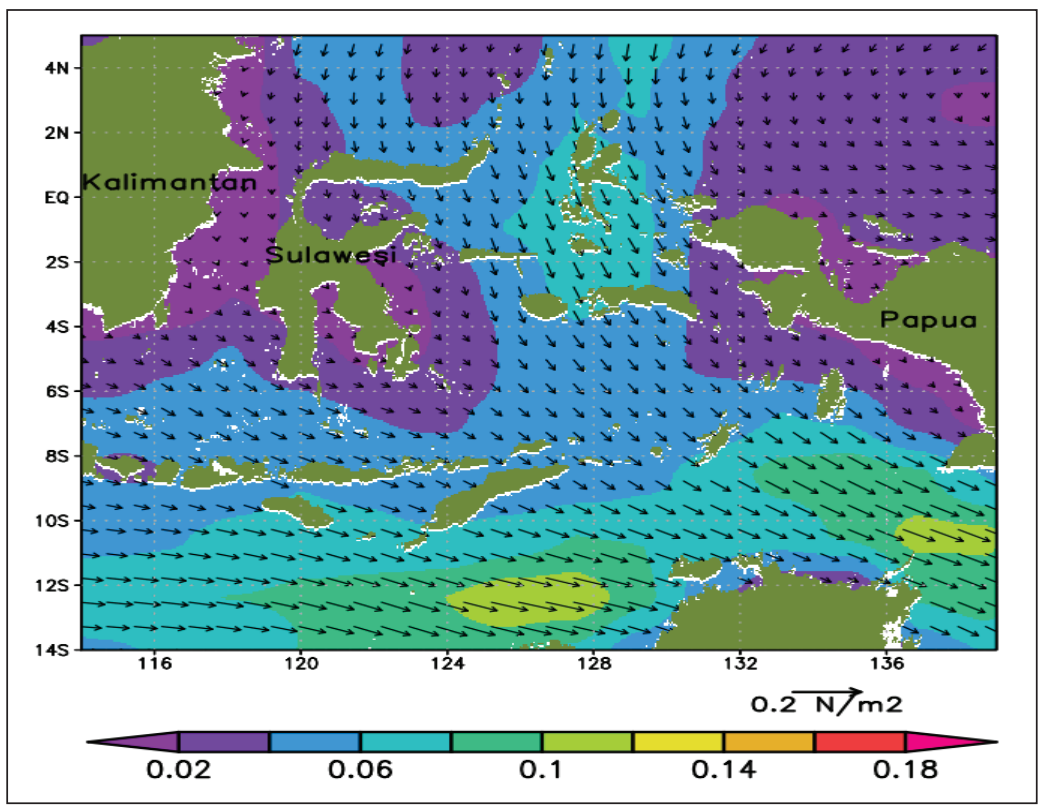

Figure 5.The horizontal distribution of monthly averaged wind stress vectors $(\mathrm{N} / \mathrm{m} 2)$ and their magnitudes (background) derived from NCEP data in the period of February 2014 in the BAS and surrounding.
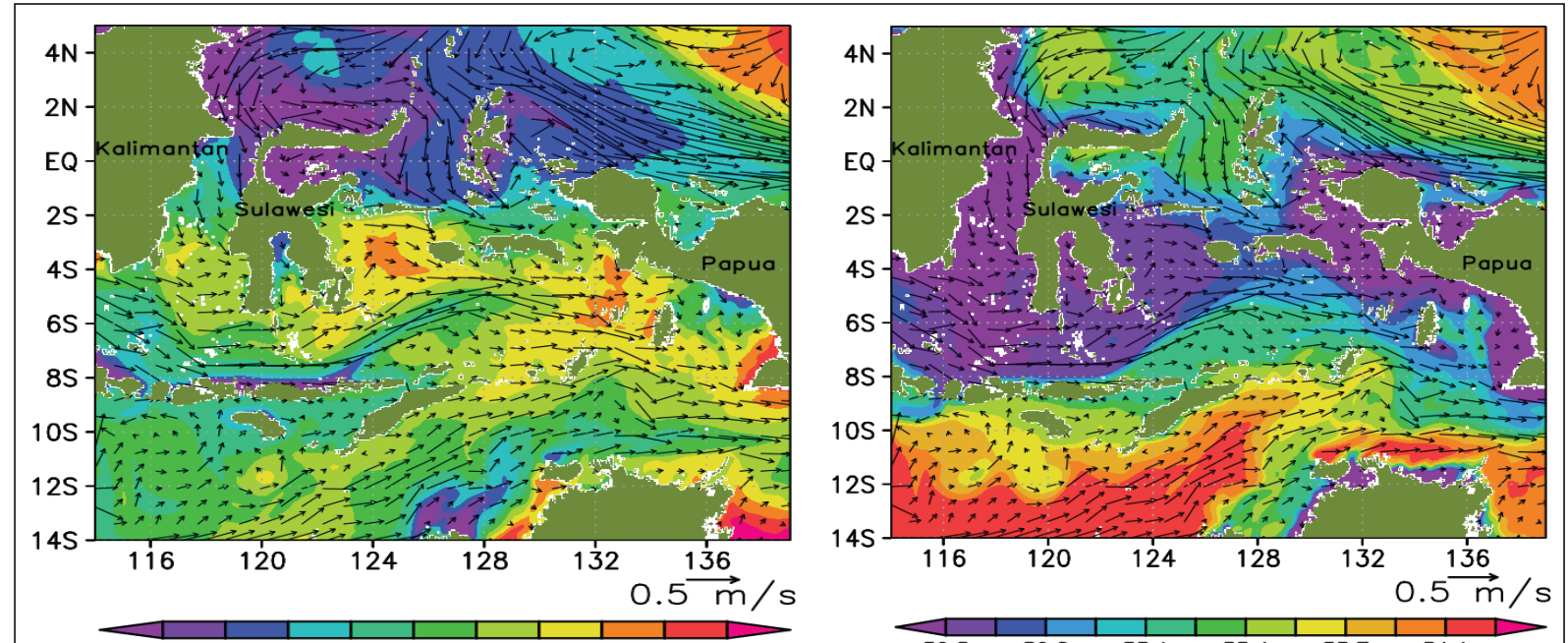

Figure 6. The horizontal distribution of monthly averaged SST (left) and SSS (right), overlaid by surface currents in February 2014 in the BAS and surrounding area, derived from the HAMSOM simulation.
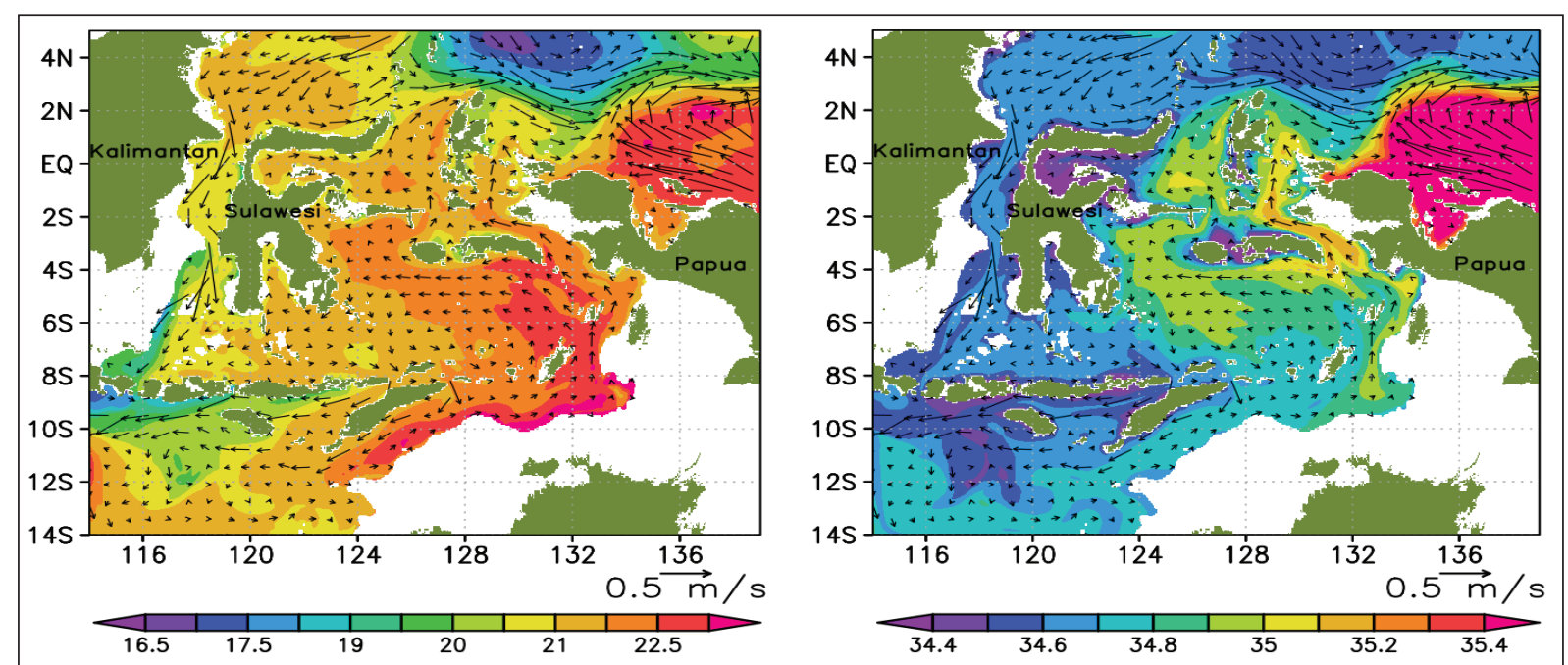

Figure 7. The horizontal distribution of monthly averaged temperature $\left({ }^{\circ} \mathrm{C}\right)$ (left) and salinity (right) at $130 \mathrm{~m}$ depth overlaid by subsurface currents in the period of February 2014 in the BAS and surrounding, derived fr HAMSOM simulation. 
exposed by the relatively saline waters coming from the Indian Ocean, which entered the region via the Ombai Strait and Timor Passage. Therefore, the southern part of the BAS was relatively more saline than the northern part. The upwelling found in this study confirms the findings of Wirasatriya et al. (2021), who suggested that offshore the Ekman Mass Transport was the main factor inducing upwelling in the area, thereby reducing SST and increasing chl-a around the northern coast of the Lesser Sunda Islands. As seen in Figure 8, a vertical profile was indicated by current vectors ( $\mathrm{v}-\mathrm{w}$ ) along Section $\mathrm{A}$. Upwelling was also indicated by upward-sloping isotherms and isohalines.

\subsection{Downwelling and its impact on the surface water in the Northern Arafura Sea}

Relatively intense downwelling was found along Section B (Figure 9). This study suggested that this downwelling was induced by the semi-enclosed nature of the Arafura Sea (Figure 1). As a consequence, little surface water could escape eastward; most was pressed downward (Figure 9), there by inducing warmer SSTs (Figure 6).

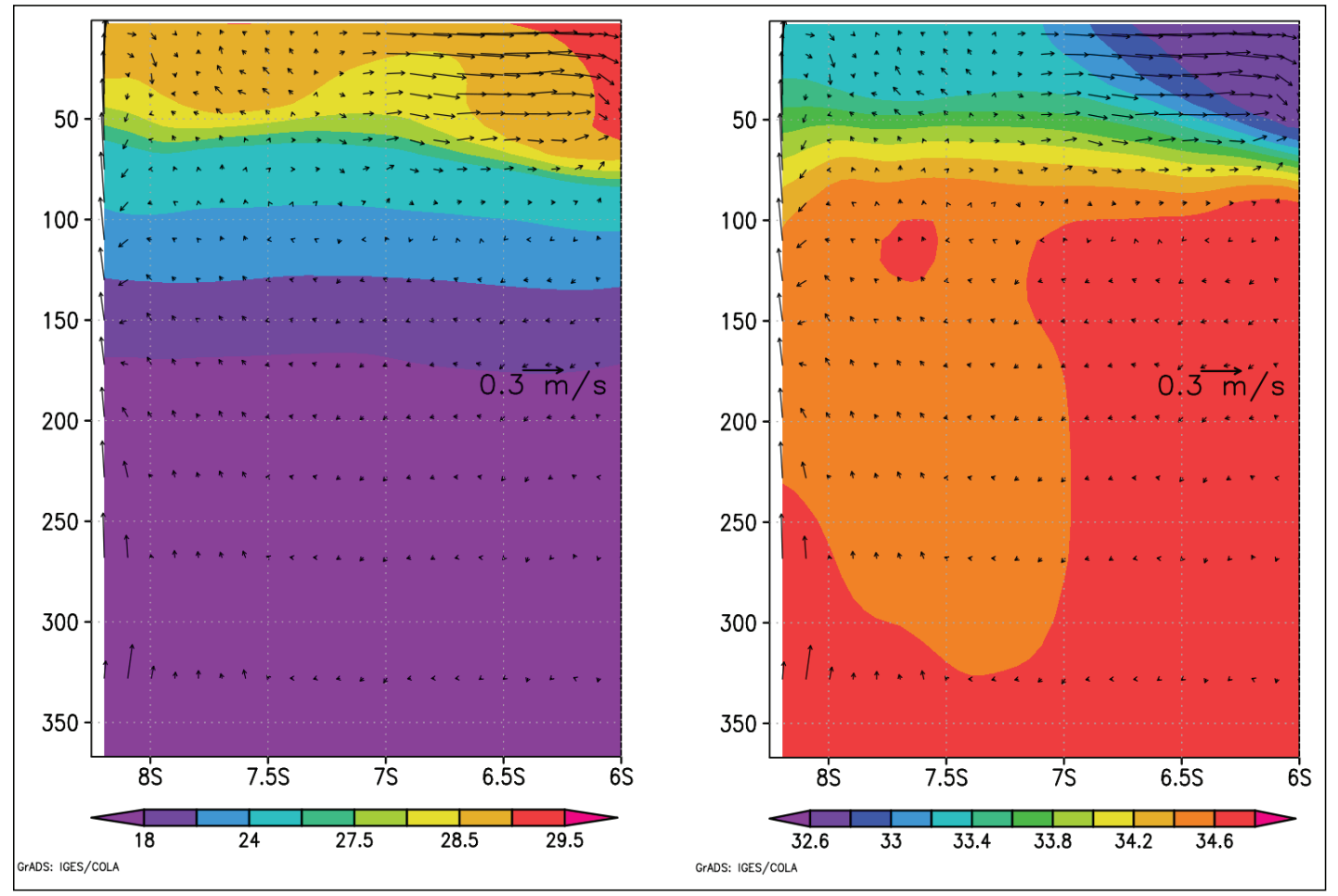

Figure 8. The vertical profile of monthly averaged $\mathrm{u}-\mathrm{w}$ velocity (where $\mathrm{u}$-velocity is in $\mathrm{m} / \mathrm{s}$ and $\mathrm{w}$-velocity is in $2 \times 10-3 \mathrm{~m} / \mathrm{s}$ ) overlaid by temperature $\left({ }^{\circ} \mathrm{C}\right)$ (left) and salinity (right) (the background) along the section $\mathrm{A}\left(8.3^{\circ} \mathrm{S}-6^{\circ} \mathrm{S}\right.$ and $\left.124^{\circ} \mathrm{E}\right)$ in the period of February 2014, derived from the HAMSOM simulation.

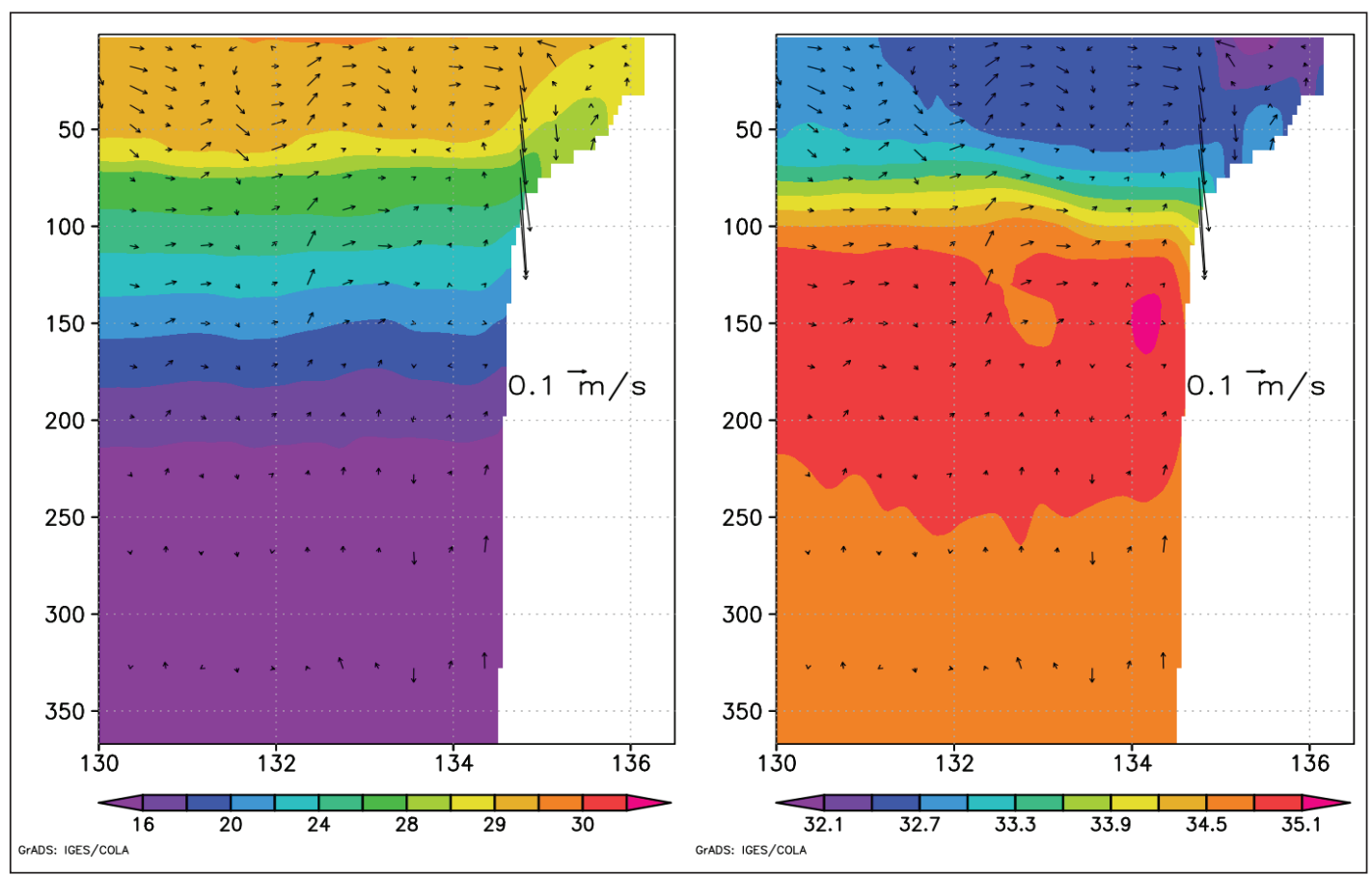

Figure 9. The vertical profile of monthly averaged $\mathrm{u}-\mathrm{w}$ velocity (where $\mathrm{u}$--velocity is in $\mathrm{m} / \mathrm{s}$ and $\mathrm{w}$-velocity is in $2 \times 10^{-3} \mathrm{~m} / \mathrm{s}$ ) overlaid by temperature $\left({ }^{\circ} \mathrm{C}\right)(\mathrm{left})$ and salinity (right) (the background) along the section $\mathrm{B}(4.6 \mathrm{~S}$ and $130 \mathrm{\circ}-136.5$ ㅌ) in the period of February 2014, derived from the HAMSOM simulation. 


\subsection{Physical conditions within the internal salinity maximum layer}

At $130 \mathrm{~m}$ depth, salinity in the Arafura Seas was found to be relatively higher than in the Banda Sea (Figure 7). The higher salinity was also found by observing the vertical profile connecting the Banda and Arafura Seas (Figure 9), confirming the findings of (Mulyadi and Basit, 2019). The simulation results suggested that the higher salinity in the Northern Arafura Sea was induced by the stronger influence of the transformed SPSW, which had a higher salinity maximum than the transformed NPSW in the Banda Sea. SPSW entered the Halmahera Sea before passing the Seram Sea and entering the Northern Arafura Sea, creating what is called the eastern Indonesian Throughflow (the eastern ITF); this mostly occurred during the southeast monsoon and followed the route shown in Figure A1. Along the route, the SPSW was transformed by tidal mixing (mostly in the Halmahera and Seram Seas); as a result, the thermocline salinity of the BAS was lower than that of the SPSW, as shown by the TS-diagram (figure not shown). These results suggest that the transformed SPSW contributed relatively little to the Banda Sea. Therefore, water within the thermocline of the Arafura Sea was generally of higher salinity than water within the thermocline of the Banda Sea. The simulation results show that the higher salinity maximum of the Northern Arafura Sea during the southeast monsoon was also found during the northwest monsoon, even though the circulation of the eastern ITF flowed in the opposite direction (Figure 7). The water masses within the thermocline water in the Northern Arafura Sea flowed northwestward to the Seram Sea and then to the Halmahera Sea before exiting into the Western Pacific Ocean during the northwest monsoon (Figure 7). The seasonal variations in the meridional velocities in the Halmahera Sea in this simulation agreed well with the findings of ( $\mathrm{Li}$ et al., 2020), as shown in Figure 5, who found northward meridional velocities within the upper thermocline layer (less than $200 \mathrm{~m}$ depth) of the Halmahera Sea during the north monsoon and southward meridional velocities during the southeast monsoon.

\section{Conclusion}

HAMSOM has proven to be a useful tool for simulating the physical and hydrodynamic conditions of the Banda and Northern Arafura Seas (BAS) during the northwest monsoon. This study showed that northwesterly winds blowing over the BAS induced northwestward currents that converged around the Northern Arafura Sea and subsequently led to downwelling around the BAS and warmer SST in the northern Aru Basin. A relatively lower SST, induced by cold waters from the northern coast of the Lesser Sunda Islands, was also found in the southwestern Band Sea. It was also found that low SSS from the Makassar Strait induced low SSS in the western Banda Sea. In contrast, relatively saline surface waters from the Indian Ocean induced higher salinity around the southern Banda Sea. In the internal salinity maximum layer, the results suggested that the SPSW induced higher salinity in the BAS. Furthermore, the salinity maxima in the Northern Arafura Sea were more visible than in the Banda Sea, indicating the weaker influence of the SPSW.

\section{Acknowledgement}

Abdul Basit contributed as the main contributor while Pipit Pitriana, Hanung Agus Mulyadi, Abd. Wahab Radjab, Mutiara Rachmat Putri, Bernhard Mayer and Thomas Pohlmann contributed as associate contributor to this manuscript.

The authors would thank Deutscher Akademischer Austauschdienst (DAAD) and Deutsches Klimarechenzentrum (DKRZ) for their financial and logistical support. We also thank the anonymous Reviewers who helped the improvement of the manuscript by providing their critical comments.

\section{References}

Backhaus, J. O. (1985). A three-dimensional model for the simulation of shelf sea dynamics. Deutsche Hydrographische Zeitschrift, 38(4), 165-187. https://doi.org/10.1007/BF02328975

Basit, A. (2019). Upwelling and Related Processes in the Banda and Northern Arafura Seas. University of Hamburg. Retrieved from https://ediss.sub.uni-hamburg.de/handle/ediss/6182

Basit, A., and Putri, M. R. (2013). Water mass characteristics of Weda Bay, Halmahera Island, North Maluku. Jurnal Ilmu Dan Teknologi Kelautan Tropis, 5(Desember), 365-376.

Egbert, G. D., Bennett, A. F., and Foreman, M. G. G. (1994). TOPEX/POSEIDON tides estimated using a global inverse model. Journal of Geophysical Research, 99(C12). https://doi. org/10.1029/94jc01894

Egbert, G. D., and Erofeeva, S. Y. (2002). Efficient inverse modeling of barotropic ocean tides. Journal of Atmospheric and Oceanic Technology, 19(2), 183-204. https://doi.org/10.1175/15200426(2002)019<0183:EIMOBO>2.0.CO;2

Explorer, N. O. (2021). NOAA Ocean Explorer: Education Multimedia Discovery Missions | Lesson 5 - Chemosynthesis and Hydrothermal Vent Life | Activities: Chemosynthesis vs. Photosynthesis. Retrieved from http://oceanexplorer.noaa.gov/ edu/learning/5_chemosynthesis/activities/chemovsphoto.html

Gordon, A. L. (2005). Oceanography of the Indonesian seas and their throughflow. Oceanography, 18(SPL.ISS. 4), 15-27. https://doi. org/10.5670/oceanog.2005.01

Gordon, A. L., Sprintall, J., Van Aken, H. M., Susanto, R. D., Wijffels, S., Molcard, R., Ffield, A., Pranowo, W., and Wirasantosa, S. (2010). The Indonesian throughflow during 2004-2006 as observed by the INSTANT program. Dynamics of Atmospheres and Oceans, 50(2), 115-128. https://doi.org/10.1016/j. dynatmoce.2009.12.002

Jungclaus, J. H., Keenlyside, N., Botzet, M., Haak, H., Luo, J. J., Latif, M., Marotzke, J., Mikolajewicz, U., and Roeckner, E. (2006). Ocean circulation and tropical variability in the coupled model ECHAM5/MPI-OM. Journal of Climate, 19(16), 3952-3972. https://doi.org/10.1175/JCLI3827.1

Kalnay, E., Kanamitsu, M., Kistler, R., Collins, W., Deaven, D., and Gandin, L. (1996). The NCEP / NCAR 40-Year Reanalysis Project.

Kaspar, F., Lehner, B., and Döll, P. (2003). A global hydrological model for deriving water availability indicators: Model tuning and validation. Journal of Hydrology, 270(1-2), 105-134. Retrieved from http://dx.doi.org/10.1016/S0022-1694(02)00283-4

Kilpatrick, K. A., Podestá, G., Walsh, S., Williams, E., Halliwell, V., Szczodrak, M., Brown, O. B., Minnett, P. J., and Evans, R. (2015). A decade of sea surface temperature from MODIS. Remote Sensing of Environment, 165, 27-41. https://doi. org/10.1016/j.rse.2015.04.023 
Koch-Larrouy, A., Madec, G., Bouruet-Aubertot, P., Gerkema, T. Bessières, L., and Molcard, R. (2007). On the transformation of Pacific water into Indonesian throughflow water by internal tidal mixing. Geophysical Research Letters, 34(4). https://doi. org/10.1029/2006GL028405

Kochergin, V. P. (1987). Three-dimensional prognostic models. In N. S. Heaps (Ed.), Three-dimensional Coastal Ocean Models (pp. 201-208). American Geophysical Union (Coastal and Estuarine Science 4) Washington, D.C.

Li, X., Yuan, D., Wang, Z., Li, Y. A. O., Corvianawatie, C., Surinati, D., Sandra, A., Bayhaqi, A., Avianto, P., Kusmanto, E. D. I., Dirhamsyah, D., and Arifin, Z. (2020). Moored observations of transport and variability of halmahera sea currents. Journal of Physical Oceanography, 50(2), 471-488. https://doi. org/10.1175/JPO-D-19-0109.1

Marsland, S. J., Haak, H., Jungclaus, J. H., Latif, M., and Röske, F. (2002). The Max-Planck-Institute global ocean/sea ice model with orthogonal curvilinear coordinates. Ocean Modelling, 5(2), 91-127. https://doi.org/10.1016/S1463-5003(02)00015-X

Mayer, B., Damm, P. E., Pohlmann, T., and Rizal, S. (2010). What is driving the ITF? An illumination of the Indonesian throughflow with a numerical nested model system. Dynamics of Atmospheres and Oceans, 50(2), 301-312. https://doi.org/10.1016/j. dynatmoce.2010.03.002

Mulyadi, H. A., and Basit, A. (2019). Dinamika kelimpahan zooplankton di laut Banda dan laut ARAFURA, Indonesia. In Prosiding Pertemuan Ilmiah Nasional Tabunan XV ISOI 2018.

Pohlmann, T. (1997a). Calculating the annual cycle of the vertical eddy viscosity in the North Sea with a three-dimensional baroclinic shelf sea circulation model. Clinical Nutrition, 16(2), 147-161.

Pohlmann, T. (1997b). Predicting the thermocline in a circulation model of the North Sea - Part I: Model description, calibration and verification. Clinical Nutrition, 16(2), 131-146.
Pohlmann, T. (2006). A meso-scale model of the central and southern North Sea: Consequences of an improved resolution. Continental Shelf Research, 26(19), 2367-2385. https://doi. org/10.1016/j.csr.2006.06.011

Sprintall, J., Gordon, A. L., Koch-Larrouy, A., Lee, T., Potemra, J. T., Pujiana, K., and Wijffels, S. E. (2014). The Indonesian seas and their role in the coupled ocean-climate system. Nature Geoscience, 7(7), 487-492. https://doi.org/10.1038/ngeo2188

Wirasatriya, A., Susanto, R. D., Kunarso, K., Jalil, A. R., Ramdani, F., and Puryajati, A. D. (2021). Northwest monsoon upwelling within the Indonesian seas. International Journal of Remote Sensing, 42(14), 5437-5458. https://doi.org/10.1080/01431 161.2021.1918790

Wyrtki, K. (1961). NAGA Report. Surface Currents in the Southeast Asian Waters, 2, 27.

\section{Declarations}

\section{Funding statement}

This research did not receive any specific grant from funding agencies in the public, commercial, or not-for-profit sectors.

\section{Conflict of interest}

The authors declare no known conflict of financial interest or personal relationships that could have appeared to influence the work reported in this paper.

\section{Additional information}

Reprints and permission information is available at https:// mri.lipi.go.id

Publisher's Note: Indonesian Institute of Sciences remains neutral with regard to jurisdictional claims in published maps and institutional affiliations.

\section{Appendix A}

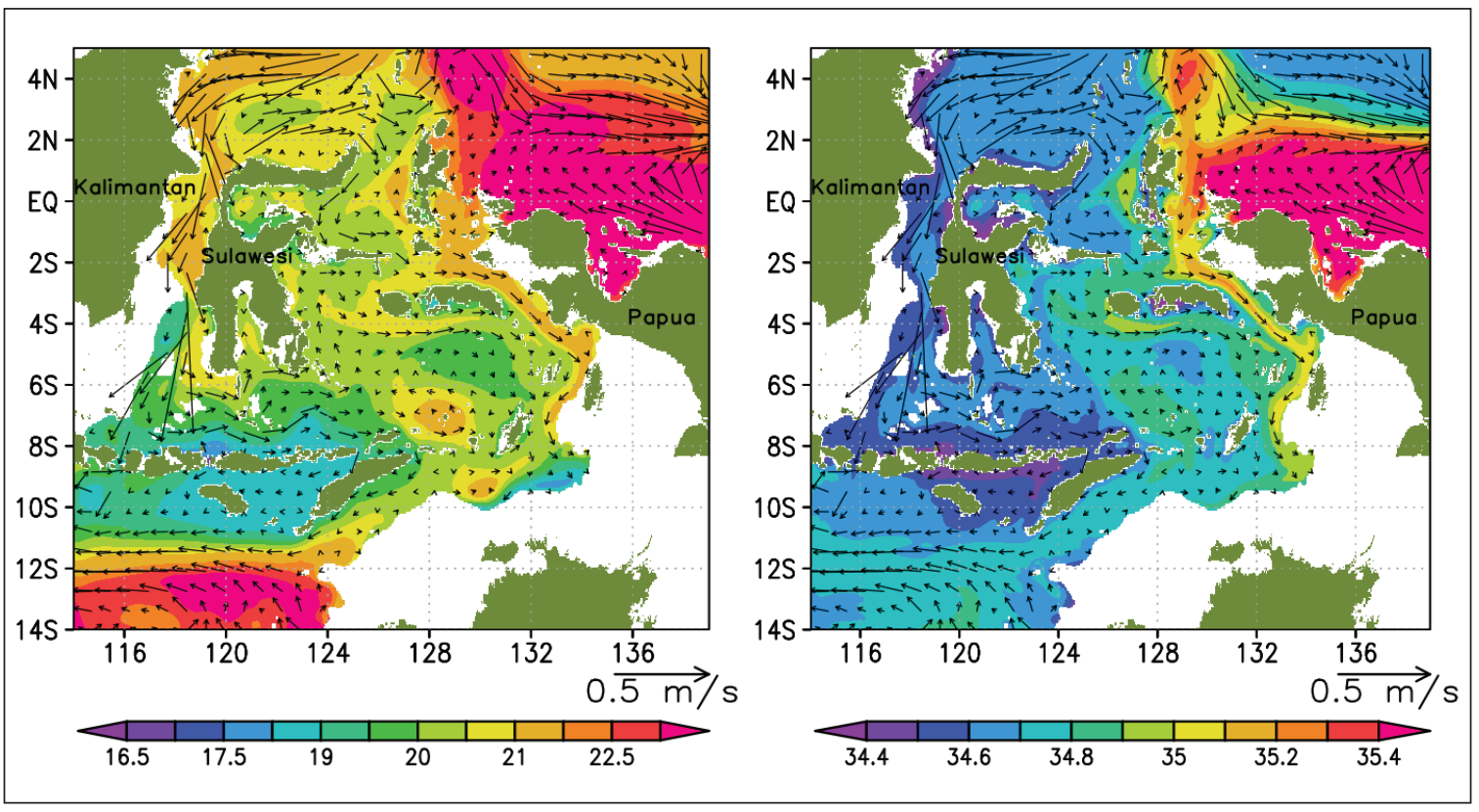

Figure A1. The horizontal distribution of seasonally averaged temperature $\left({ }^{\circ} \mathrm{C}\right)(\mathrm{left})$ and salinity (right) at $130 \mathrm{~m}$ depth overlaid by subsurface currents during souteast monsoon (May-September 2014) in the BAS and surrounding, derived from the HAMSOM simulation. 